\title{
ISOLASI, SELEKSI, DAN IDENTIFIKASI BAKTERI DARI SALURAN PENCERNAAN IKAN LELE SEBAGAI KANDIDAT PROBIOTIK
}

\author{
Titin Kurniasih", Widanarni"), Mulyasari"), Irma Melati", Zafril Imran Azwar"), \\ dan Angela Mariana Lusiastuti") \\ ") Balai Penelitian dan Pengembangan Budidaya Air Tawar \\ Jl. Sempur No. 1, Bogor 16154 \\ E-mail: titink2008@yahoo.com \\ *) Pusat Penelitian dan Pengembangan Perikanan Budidaya \\ Jl. Ragunan 20, Pasar Minggu, Jakarta Selatan 12450
}

(Naskah diterima: 5 April 2012; Disetujui publikasi: 2 April 2013)

\begin{abstract}
ABSTRAK
Penambahan probiotik pada pakan telah banyak diaplikasikan pada kegiatan akuakultur dan terbukti bermanfaat meningkatkan pertumbuhan dan efisiensi pakan ikan. Probiotik yang ditujukan untuk membantu meningkatkan aktivitas pencernaan dalam saluran pencernaan ikan, akan lebih baik apabila diisolasi dari saluran pencernaan ikan itu sendiri. Penelitian ini bertujuan untuk mendapatkan bakteri probiotik dari saluran pencernaan ikan lele, mengisolasi, menyeleksi, serta mengidentifikasi bakteri yang didapatkan. Lambung dan usus lele, digerus dan diencerkan, kemudian dikultur dengan teknik cawan sebar. Koloni yang didapat dimurnikan dan diseleksi dengan uji zona hidrolisis protein dan uji patogenisitas, dan diidentifikasi secara biokimiawi dan molekuler. Tahap isolasi mendapatkan 10 isolat, tahap uji zona hidrolisis protein mendapatkan 4 isolat dengan zona hidrolisis tertinggi, sedangkan uji patogenisitas hanya meloloskan 2 isolat, yaitu A1 dan L1. Hasil uji identifikasi biokimiawi dan molekuler menunjukkan bahwa isolat A1 adalah Staphylococcus epidermidis dan L1 adalah Bacillus cereus. Bacillus cereus merupakan spesies yang sebagian besar anggotanya merupakan probiotik bagi hewan darat dan ikan, dengan demikian dari penelitian ini didapatkan bahwa Bacillus cereus merupakan kandidat bakteri yang berpeluang untuk dijadikan probiotik.
\end{abstract}

KATA KUNCl: isolasi, seleksi, probiotik, saluran pencernaan, ikan lele

ABSTRACT: The isolation, selection, and identification of probiotic bacteria as candidate isolated from the gastrointestinal tract of African catfish Clarias gariepinus. By: Titin Kurniasih, Widanarni, Mulyasari, Irma Melati, Zafril Imran Azwar, and Angela Mariana Lusiastuti

The use of dietary probiotics in fish and shrimp diets is well documented and appeared to be effective to improve fish and shrimp production. In order to obtain candidate bacteria that can be use as probiotics, which play an important role on the digestive tract of fish, a selective isolation from gastrointestinal tract of the fish is suggested. This research aimed to obtain candidate bacteria as probiotic that were collected from the gastrointestinal track of African catfish followed by isolation, selection, and identification of the selected candidate bacteria. The stomach and intestine were crushed, diluted, and inoculated onto agar medium. The growing colonies were purified, and then selected based on their maximum clear zone diameter on casein agar 
medium and the absence of pathogenic activity against the test fish. The selected isolates were identified using biochemical and molecular determination. From the 10 of pure isolates obtained, 4 isolates revealed the longest clear zone diameter. The two isolates designated as $A 1$ and $L 1$ did not performed pathogenic activity against the test fish. Result of biochemical and molecular identification showed that Al was Staphylococcus epidermidis and LI was Bacillus cereus. Most of the strains of Bacillus cereus have been shown to be an effective probiotics for terrestrial and aquatic animal, therefore this study has concluded that Bacillus cereus is a strong candidate to be used as probiotics.

\section{KEYWORDS: isolation, selection, probiotics, feed efficiency, African catfish}

\section{PENDAHULUAN}

Problema efisiensi pakan pada dunia perikanan merupakan masalah yang belum terselesaikan. Harga bahan pakan yang semakin tinggi dan sukar diperoleh, karena sebagian besar diimpor, merupakan penyebab utama bagi timbulnya masalah ini. Makanan terbuang dan tidak sempat dikonsumsi ikan memang tidak akan pernah terelakkan, disebabkan oleh kondisi alam berupa air dan tingkah laku ikan itu sendiri. Akan tetapi makanan atau nilai nutrisi yang terbuang setelah dikonsumsi ikan akibat rendahnya tingkat kecernaan pakan tentu teramat disayangkan.

Probiotik merupakan suplemen tambahan berupa sel-sel mikroba hidup, yang memiliki pengaruh menguntungkan bagi hewan inang yang mengonsumsinya melalui penyeimbangan flora mikroba intestinalnya (Fuller, 1987). Verschuere et al. (2000) menyatakan bahwa probiotik merupakan suplemen mikroba hidup yang memiliki pengaruh menguntungkan bagi komunitas mikroba lingkungan hidupnya. Dalam peningkatan nilai nutrisi pakan, probiotik mampu menghasilkan beberapa enzim eksogenus yang berguna untuk membantu mencerna pakan seperti enzim amilase, protease, lipase, dan selulase (Sahu et al., 2008; Wang et al., 2008) yang biasanya dimiliki oleh ikan dan makhluk air lainnya dalam jumlah terbatas. Meningkatnya daya cerna ikan akan membantu meningkatkan efisiensi pakan dan menurunkan besarnya nutrisi yang terbuang melalui feses.

Bakteri proteolitik adalah jenis bakteri penghasil enzim protease, yang berfungsi meningkatkan kemampuan ikan mencerna protein, sehingga buangan protein atau nitrogen melalui feses akan berkurang. Bakteri proteolitik terbukti bermanfaat untuk ikan (Nopitawati, 2010). Bakteri proteolitik umum ditemui pada usus lele. Lele adalah hewan omnivora dengan usus yang pendek, menyebabkan lele harus beradaptasi dengan meningkatkan laju kecernaannya. Adanya bakteri proteolitik pada saluran pencernaan lele, adalah salah satu adaptasi lele dalam mencerna substansi kompleks berupa protein dalam waktu yang sangat singkat.

Menurut Watson et al. (2008), persyaratan yang harus dimiliki oleh mikroba probiotik pada saat diseleksi antara lain adalah tidak bersifat patogen atau mengganggu inang dan konsumen (manusia dan hewan lainnya), tidak mengganggu keseimbangan ekosistem setempat, mudah dipelihara dan diperbanyak, serta dapat bertahan hidup dan berkembang biak di dalam usus ikan. Agar bakteri probiotik dapat bertahan hidup dalam saluran pencernaan ikan dan menjalankan fungsinya ketika diberikan melalui pakan, maka akan lebih baik apabila probiotik diisolasi dari saluran pencernaan ikan itu sendiri, sehingga kemampuan daya hidupnya dalam saluran pencernaan ikan sudah teruji. Penelitian yang bertujuan mendapatkan probiotik dari saluran pencernaan ikan telah banyak dilakukan antara lain ikan bandeng (Aslamyah, 2006), udang vaname (Nopitawati, 2010), ikan jelawat (Sabariah, 2010), dan ikan nila (Putra, 2010), dan aplikasinya pada pakan menunjukkan hasil yang signifikan untuk pertumbuhan dan efisiensi pakan ikan. Berpijak dari hasil-hasil ini, maka dibangun satu kerangka pemikiran untuk mengisolasi, menyeleksi, dan mengidentifikasi bakteri proteolitik pendegradasi protein dari saluran pencernaan ikan lele, sebagai langkah awal studi probiotik untuk meningkatkan efisiensi pakan ikan.

\section{BAHAN DAN METODE}

Kegiatan isolasi, seleksi, dan identifikasi biokimia bakteri proteolitik dilakukan di Laboratorium Mikrobiologi Nutrisi, Balai Riset 
Perikanan Budidaya Air Tawar (BRPBAT) Bogor. Kegiatan identifikasi bakteri secara molekular dilakukan di Laboratorium Bioteknologi Puspiptek BPPT Serpong.

\section{Isolasi Bakteri Proteolitik}

Prosedur isolasi bakteri yang mempunyai aktivitas proteolitik dilakukan dengan metode selektif, yang mengacu pada metode yang dilakukan pada hewan darat seperti petunjuk Hungate (1966), serta mengombinasikannya dengan prosedur isolasi bakteri dari saluran pencernaan ikan seperti yang dilakukan oleh Nakayama et al. (1994); Hoshino et al. (1997); Cai et al. (1998); dan Jankauskiene (2000).

Sumber inokulum berasal dari saluran pencernaan ikan lele dan air kolam pemeliharaan ikan lele sebagai pembanding. Isolasi bakteri proteolitik dimulai dengan pemilihan individu lele yang telah berumur 2-3 bulan dengan bobot sekitar 100-150 g dengan kondisi badan yang sehat dan tanpa cacat fisik. Pemilihan kondisi fisik lele dilakukan untuk mendapatkan lele dengan kondisi pencernaan yang baik.

Pengambilan isi saluran pencernaan ikan lele sebagai sumber inokulum dilakukan dengan cara mengeluarkan saluran pencernaan (lambung dan usus) dari ikan lele dewasa yang telah dimatikan. Lambung dan usus digerus, kemudian sebanyak $1 \mathrm{~g}$ ditambah dengan $1 \mathrm{~mL}$ cairan fisiologis ( $\mathrm{NaCl} 0,85 \%)$ steril (Aslamyah, 2006) dan dihomogenkan dengan vortex. Sumber inokulum diambil sebanyak $1 \mathrm{~mL}$ dan diencerkan dalam tabung pengenceran serial yang berisi $9 \mathrm{~mL}$ larutan fisiologis, sebanyak 10 tabung pengencer (hingga pengenceran $10^{10} \mathrm{kali}$ ). Setelah dihomogenkan, maka dari setiap tabung pengencer diambil larutan sebanyak 0,1 mL; dan disebarkan dalam cawan petri berisi TSA yang dibuat secara duplo. Kultur ini kemudian diinkubasi pada suhu $29^{\circ} \mathrm{C}$ selama $24-48$ jam sampai koloni bakteri dapat tumbuh, dalam suasana aerob.

Koloni bakteri yang tumbuh diidentifikasi berdasarkan perbedaan warna, bentuk, dan ukurannya. Setiap jenis koloni yang didapat dimurnikan dengan metode penggoresan kuadran, sampai didapatkan koloni bakteri yang tunggal dan seragam.

Kultur murni selanjutnya diperbanyak atau diperkaya untuk mendapatkan isolat. Sebagian isolat bakteri digunakan sebagai kultur stok dan sebagian lagi dipakai sebagai inokulum pada percobaan berikutnya. Pengayaan dilakukan dengan cara menumbuhkan masingmasing isolat ke dalam media TSB kemudian diinkubasi pada suhu $29^{\circ} \mathrm{C}$ selama 24 jam. Kultur yang didapat siap untuk diawetkan. Pengawetan dilakukan dengan menyimpan isolat-isolat yang telah diperoleh ke dalam media gliserol 15\%-20\% yang selanjutnya disebut kultur stok.

\section{Seleksi Bakteri Proteolitik}

Untuk mendapatkan bakteri yang berpotensi tinggi sebagai penghasil enzim protease, maka seleksi bakteri dilakukan melalui tahapan pengujian aktivitas proteolitik dan pengujian patogenisitas. Pengujian aktivitas proteolitik bertujuan untuk mengukur besarnya aktivitas proteolitik masing-masing isolat dengan uji hidrolisis kasein. Aktivitas proteolitik ditandai dengan adanya zona bening di sekeliling isolat yang ditumbuhkan pada media agar yang mengandung kasein $2 \%$.

Uji hidrolisis kasein dilakukan dengan menyiapkan media kultur agar yang mengandung kasein $2 \%$ dalam cawan petri, membagi wilayah agar menjadi empat bagian (kuadran) yang sama, dan menempatkan empat buah kertas cakram di bagian tengah setiap kuadran. Sebanyak $0,1 \mathrm{~mL}$ kultur cair isolat yang akan diuji dipipet dan diteteskan di satu kertas cakram, sehingga satu cawan petri dapat digunakan untuk empat isolat yang berbeda. Biakan diinkubasi pada suhu $29^{\circ} \mathrm{C}$ selama 24 sampai $48 \mathrm{jam}$. Proses hidrolisis protein akan teramati dengan terbentuknya daerah bening di sekeliling koloni mikrob, sebaliknya bila tidak terjadi hidrolisis daerah sekitar koloni tetap berwarna keruh. Panjang diameter zona bening ini diukur.

Pengujian patogenisitas bertujuan untuk mengetahui apakah isolat bakteri yang diperoleh merupakan bakteri patogen terhadap ikan uji atau tidak. Masing-masing isolat disuntikkan pada kelompok ikan lele sehat (terdiri atas lima ekor pada setiap akuarium) secara intramuscular sebanyak $0,2 \mathrm{~mL}$ dengan kandungan bakteri sebanyak $10^{7} \mathrm{CFU} / \mathrm{mL}$. Sebagai kontrol digunakan larutan fisiologis yang juga disuntikkan pada satu kelompok ikan lele. Pemantauan dilakukan setiap hari selama dua minggu setelahnya, apakah didapatkan perbedaan mortalitas apabila dibandingkan 
dengan kontrol, atau adanya tanda klinis penyakit pada ikan uji.

\section{Identifikasi Bakteri Terpilih}

Identifikasi bakteri proteolitik dilakukan dengan metode uji biokimia standar yang diawali dengan pewarnaan gram dan spora untuk mendeteksi morfologi awal dari bakteri. Kunci determinasi yang digunakan merujuk pada kunci determinasi Bergey's Determinative Bacteriology dengan melakukan serangkaian uji morfologi dan biokimia yaitu bentuk bakteri, uji pewarnaan gram, uji acid fast, uji katalase, uji pewarnaan spora, fermentasi glukosa dan laktosa, uji oksidase, oksidatif/ fermentatif (OF), motility, serta pertumbuhan aerobik dan anerobik.

\section{HASIL DAN BAHASAN}

\section{Isolasi Bakteri Proteolitik}

Kegiatan isolasi bakteri dari saluran pencernaan ikan lele dan kolam pemeliharaan ikan berturut-turut mendapatkan tujuh dan tiga isolat yang dipilih berdasarkan perbedaan morfologi koloninya. Koloni-koloni bakteri yang didapatkan memiliki karakter morfologis antara lain bulat kecil, bulat sedang, bulat besar, dan warna yang didapatkan adalah putih kusam, putih susu, krem, kuning, dan bening.

Koloni bakteri proteolitik memiliki beberapa ciri khas morfologis yang khas, berbentuk bulat dengan pinggiran yang halus, ditemukan ada penggumpalan pada koloni sehingga akan tampak menggunung apabila dilihat dari samping agar.

\section{Seleksi Bakteri Proteolitik}

\section{Aktivitas Proteolitik}

Hasil uji aktivitas proteolitik bakteri hasil isolasi disajikan pada Gambar 1. Aktivitas proteolitik positif ditandai dengan adanya zona bening di sekeliling koloni isolat, yang merupakan luas areal hidrolisis substrat kasein oleh isolat bakteri.

Hasil pengukuran luas diameter aktivitas proteolitik disajikan pada Tabel 1. Empat bakteri dengan diameter hidrolisis kasein tertinggi adalah A1, L1, L3, dan L4 yang menghasilkan zona bening dengan diameter berturut-turut sebesar 30, 28, 25, dan $28 \mathrm{~mm}$. Enam isolat lainnya tidak terpilih untuk mengikuti pengujian patogenisitas karena zona hidrolisis kaseinnya terlalu sempit (11, $10,8,8,6$, dan $5 \mathrm{~mm}$ ). Keempat bakteri tersebut selanjutnya mengikuti pengujian patogenisitas.

Luas zona hidrolisis kasein dijadikan sebagai dasar acuan pertama dalam seleksi bakteri proteolitik, yang mengindikasikan kemampuannya dalam memanfaatkan protein untuk kelangsungan hidupnya, dengan terlebih dahulu merombak protein menjadi asamasam amino. Meskipun menurut Suhartono (1989), dalam beberapa kasus, luas zona hidrolisis kasein tidak secara otomatis langsung berkorelasi dengan produktivitasnya dalam menghasilkan enzim protease, namun metode ini masih cukup efektif untuk seleksi awal. Gupta \& Khare (2006) dan Tang (2008) juga melakukan metode zona bening ini untuk menyeleksi bakteri proteolitik, dan pada tahap
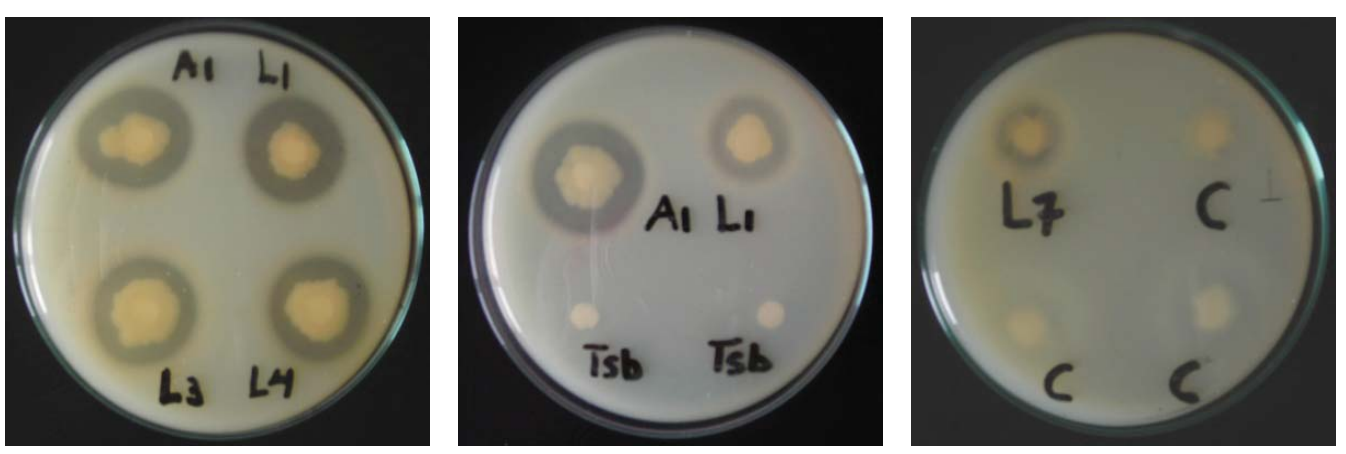

Gambar 1. Zona bening hasil hidrolisis kasein dalam medium agar sebagai hasil aktivitas proteolitik oleh bakteri A1, L1 , L3, L4, dan L7, bakteri non proteolitik (C) dan TSB

Figure 1. The clear zone of hydrolyzed casein on agar medium as the result of proteolytic activity by $A 1, L 1, L 3, L 4$, and $L 7$ bacteria, non proteolytic bacteria (C) and TSB 
Tabel 1. Diameter zona bening hasil hidrolisis kasein dari kesepuluh isolat bakteri pada medium agar

Table 1. Diameter of clear zone of hydrolized casein of the ten isolates on agar medium

\begin{tabular}{cc}
\hline $\begin{array}{c}\text { Isolat } \\
\text { Isolates }\end{array}$ & $\begin{array}{c}\text { Diameter hidrolisis } \\
\text { Clear zone diameter }(\mathbf{m m})\end{array}$ \\
\hline A1 & 30 \\
L1 & 28 \\
L4 & 28 \\
L3 & 25 \\
L7 & 11 \\
L2 & 10 \\
L6 & 8 \\
A2 & 8 \\
A3 & 6 \\
L5 & 5 \\
\hline
\end{tabular}

terakhirnya memperoleh Pseudomonas aeruginosa yang mampu memproduksi protease dalam jumlah besar.

\section{Uji Patogenisitas}

Uji patogenisitas bertujuan untuk mengetahui apakah isolat yang didapatkan bersifat patogen terhadap ikan uji atau tidak. Pengujian dilakukan terhadap 4 bakteri yang memiliki zona hidrolisis kasein tertinggi (A1, L1 , L3, dan L4) dan larutan fisiologis sebagai kontrol menggunakan ikan lele sebagai ikan uji.

Hasil uji patogenisitas yang dilakukan selama dua minggu di akuarium disajikan pada Tabel 2. Tingkat sintasan ikan lele yang diinjeksi isolat A1 dan L1 sebesar 100\% hingga akhir masa pengamatan, sama dengan kontrol, yang mengindikasikan bahwa isolat $\mathrm{A} 1$ dan $\mathrm{L} 1$ tidak bersifat patogen terhadap ikan lele. Tingkat sintasan ikan lele pada perlakuan injeksi isolat L3 dan L4 hanya $40 \%$ dan $20 \%$ di akhir pengamatan.

Tabel 2. Hasil uji patogenisitas isolat bakteri proteolitik

Table 2. Test of the pathogenic activity against the test fish

\begin{tabular}{|c|c|c|c|c|}
\hline $\begin{array}{c}\text { Isolat uji } \\
\text { Test isolates }\end{array}$ & $\begin{array}{c}\text { JIA } \\
\text { (ekor/ind.) }\end{array}$ & $\begin{array}{c}\text { JIM } \\
\text { (ekor/ind.) }\end{array}$ & $\begin{array}{l}\text { SR } \\
\text { (\%) }\end{array}$ & $\begin{array}{l}\text { Ket erangan } \\
\text { Description }\end{array}$ \\
\hline $\mathrm{A} 1$ & 5 & 0 & 100 & $\begin{array}{l}\text { Ikan uji sehat dan aktif hingga akhir } \\
\text { masa pe mantauan (The test fish is } \\
\text { healthy and active until the end of the } \\
\text { periode of observation) }\end{array}$ \\
\hline L1 & 5 & 0 & 100 & $\begin{array}{l}\text { Ikan uji se hat dan aktif hingga akhir } \\
\text { masa pe mantauan (The test fish is } \\
\text { healthy and active until the end of the } \\
\text { periode of observation) }\end{array}$ \\
\hline L4 & 5 & 4 & 20 & $\begin{array}{l}\text { Ikan yang masih hidup kurang gesit di } \\
\text { akhir masa pemantauan (The surviving } \\
\text { fish are less active in the end of the } \\
\text { periode of observation) }\end{array}$ \\
\hline L3 & 5 & 3 & 40 & $\begin{array}{l}\text { Ikan yang masih hidup kurang gesit di } \\
\text { akhir masa pemantauan (The surviving } \\
\text { fish are less active in the end of the } \\
\text { periode of observation) }\end{array}$ \\
\hline Kontrol (Control) & 5 & 0 & 100 & Ikan uji sehat (The test fish are healthy) \\
\hline
\end{tabular}

Keterangan (Note):

JIA = Jumlah ikan awal (The initial number of the test fish), JIM = Jumlah ikan mati (The number of the dead fish), SR = Survival rate 
Berdasarkan analisis secara deskriptif, isolat A1 dan L1 terpilih sebagai bakteri penghasil enzim protease pada percobaan selanjutnya. Pertimbangannya adalah berdasarkan peringkatnya yang tertinggi pada uji zona hidrolisis kasein, dan terbukti tidak bersifat patogen pada ikan lele.

\section{Identifikasi Bakteri Terpilih}

Hasil dari uji biokimia determinatif isolat bakteri A1 dan L1 tersaji di Tabel 3. Karakter biokimiawi kedua isolat dirujukkan kepada buku pedoman determinatif Bergey's untuk ditelusuri spesies dari bakteri target. Hasil penelusuran ternyata merujuk pada bakteri Staphyllococcus epidermidis untuk bakteri A1 dan Bacillus cereus untuk bakteri L1 .

Hasil identifikasi kedua isolat secara molekuler dengan sekuensi DNA semakin menguatkan hasil identifikasi secara biokimia (Gambar 2). Berdasarkan sekuensi DNA-nya terbukti bahwa isolat $\mathrm{Al}$ adalah $\mathrm{S}$. epidermidis dan isolat $\mathrm{L} 1$ adalah $B$. cereus dengan indeks kesamaan $100 \%$.

Dari Gambar 2 terlihat bahwa bakteri A1, yang di dalam pohon filogenetik (kiri) dilambangkan sebagai $B$, berkerabat sangat dekat dengan S. epidermidis strain LEH7 1A, sedangkan kerabatnya yang bersebelahan anak cabang, adalah S. epidermidis strain SR 1 . Ini mengindikasikan bahwa secara molekuler, bakteri A1 memang benar-benar S. epidermidis. Bakteri L1 yang di dalam pohon filogenetik (kanan) dilambangkan sebagai A, berkerabat sangat dekat dengan B. cereus strain MT 53, sedangkan kerabat dekatnya yang berbeda anak cabang, sebagian besar juga $B$. cereus strain lain. Ini mengindikasikan bahwa secara molekuler, bakteri L1 memang benar-benar $B$. cereus.

Bacillus cereus merupakan bakteri grampositif, berukuran $1 \times 3-4 \mu \mathrm{m}$ dan selnya berbentuk batang besar, bersifat aerob fakultatif, mesophilik, yaitu tumbuh optimal pada suhu

Tabel 3. Hasil uji identifikasi biokimia isolat bakteri terseleksi

Table 3. The result of biochemical identification of the selected bacterial

\begin{tabular}{|c|c|c|}
\hline $\begin{array}{l}\text { Uji biokimiawi } \\
\text { Biochemical test }\end{array}$ & $\begin{array}{c}\mathrm{Ll} \\
\text { (Bacillus cereus) }\end{array}$ & $\begin{array}{c}\text { Al (Staphylococcus } \\
\text { epidermidis) }\end{array}$ \\
\hline $\begin{array}{l}\text { Pewarnaan gram } \\
\text { Gram staining }\end{array}$ & $\begin{array}{l}\text { Gram positif } \\
\text { Gram-positive }\end{array}$ & $\begin{array}{l}\text { Gram positif } \\
\text { Gram-positive }\end{array}$ \\
\hline $\begin{array}{l}\text { Pewarnaan Ziehl Nielsen } \\
\text { Ziehl Nielsen Staining }\end{array}$ & $\begin{array}{l}\text { Negatif } \\
\text { Negative }\end{array}$ & $\begin{array}{l}\text { Negatif } \\
\text { Negative }\end{array}$ \\
\hline Katalase (Catalase test) & Positif (Positive) & Positif (Positive) \\
\hline $\begin{array}{l}\text { Pewarnaan spora } \\
\text { Spore staining }\end{array}$ & $\begin{array}{l}\text { Berspora } \\
\text { Spore }\end{array}$ & $\begin{array}{l}\text { Tidak berspora } \\
\text { Non spore }\end{array}$ \\
\hline Bentuk (Shape) & Basil (Bacillus) & Kokus (Cocci) \\
\hline $\begin{array}{l}\text { Fermentasi glukosa } \\
\text { Glucose fermentation }\end{array}$ & $\begin{array}{l}\text { Positif } \\
\text { Positive }\end{array}$ & $\begin{array}{l}\text { Positif } \\
\text { Positive }\end{array}$ \\
\hline $\begin{array}{l}\text { Fermentasi laktosa } \\
\text { Lactose fermentation }\end{array}$ & $\begin{array}{l}\text { Negatif } \\
\text { Negative }\end{array}$ & $\begin{array}{l}\text { Positif } \\
\text { Positive }\end{array}$ \\
\hline Uji oksidase (Oxidase test) & Negatif (Negative) & Negatif (Negative) \\
\hline $\begin{array}{l}\text { Uji oksidatif fermentatif } \\
\text { Oxidative-fermentative test }\end{array}$ & $\begin{array}{l}\text { Fermentatif } \\
\text { Fermentative }\end{array}$ & $\begin{array}{l}\text { Fermentatif } \\
\text { Fermentative }\end{array}$ \\
\hline Motilitas (Motility) & Motil (Motile) & Non motil (Non motile) \\
\hline $\begin{array}{l}\text { Pertumbuhan ae robic } \\
\text { Aerobic growth }\end{array}$ & $\begin{array}{l}\text { Positif } \\
\text { Positive }\end{array}$ & $\begin{array}{l}\text { Positif } \\
\text { Positive }\end{array}$ \\
\hline $\begin{array}{l}\text { Pertumbuhan anaerobic } \\
\text { Anaerobic growth }\end{array}$ & $\begin{array}{l}\text { Positif } \\
\text { Positive }\end{array}$ & $\begin{array}{l}\text { Positif } \\
\text { Positive }\end{array}$ \\
\hline
\end{tabular}


Al

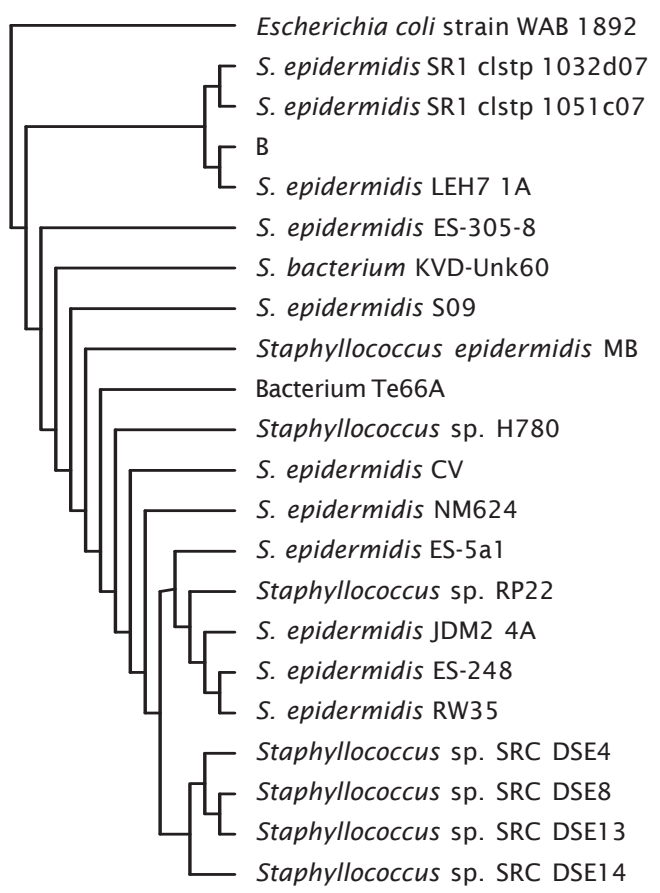

L1

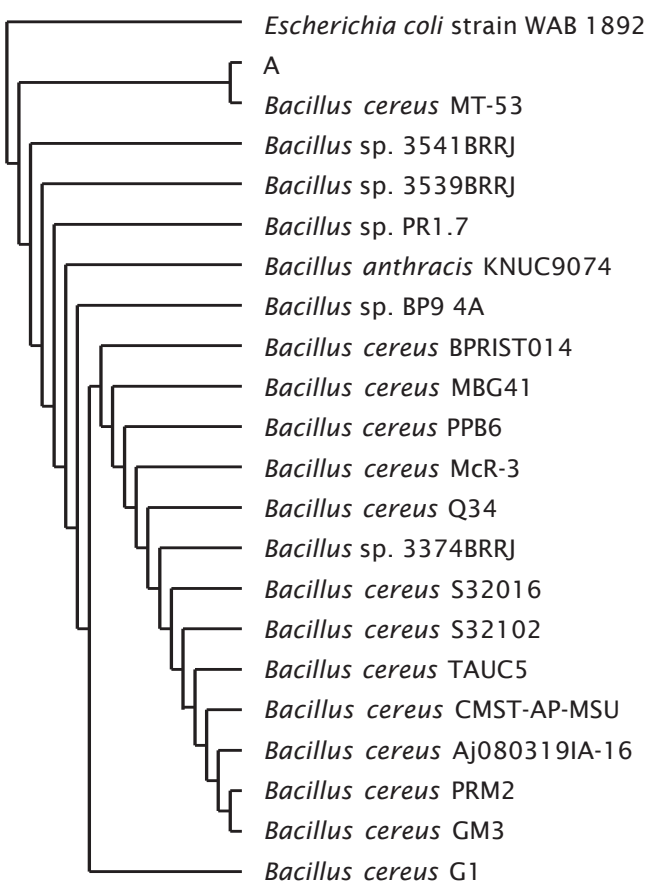

Gambar 2. Dendogram filogenetik isolat A1 dan L1

Figure 2. The phylogenetic dendogram of the $A 1$ and $L 1$ bacterias

antara $20^{\circ} \mathrm{C}$ dan $40^{\circ} \mathrm{C}$, dan mampu beradaptasi terhadap kondisi lingkungan pada kisaran yang luas (Villain et al., 2006). B. cereus bersifat motil karena memiliki flagella dan menunjukkan 2 jenis pergerakan yaitu berenang dan bergerombol, tergantung pada kondisi lingkungannya (Senesi et al., 2002).

Bacillus cereus tersebar luas di alam dan pada berbagai sumber makanan baik hewani, nabati, telur, susu, dan air, dan ditemukan di tanah sebagai organisme saprofit (Villain et al., 2006). Sebagian strainnya berbahaya bagi manusia karena menimbulkan infeksi lewat makanan, namun sebagian lainnya bermanfaat sebagai probiotik untuk hewan (Ryan et al., 2004).

Bacillus cereus memiliki kromosom berbentuk sirkular sepanjang 5,411,809 nt dan telah disekuensi secara lengkap menggunakan metode sekuensing Shotgun. (Rasko et al., 2005). Struktur genomnya terdiri atas 5.481 gen, 5.234 kode protein, 147 RNA struktural, dan 5.366 operon RNA. Sebuah cluster gene yang menarik ditemukan dalam genomnya, yang diduga berperan dalam daya hidup bakteri ini, yang memungkinkannya untuk bertahan hidup dalam suasana asam (Rasko et al., 2004). Selain itu, B. cereus memiliki cluster gene urease, yang dapat meningkatkan ketahanan hidup di dalam suasana asam dan diperlukan dalam proses kolonisasi dalam saluran cerna (Rasko et al., 2004).

Sebagaimana anggota genus Bacillus lainnya, $B$. cereus dapat membentuk endospora yang berguna untuk mempertahankan daya hidupnya. B. cereus membentuk spora ketika nutrien menipis di lingkungannya dan kembali menjadi sel vegetatif ketika nutrien tersedia lagi (Wijnands et al., 2006).

B. cereus berkompetisi dengan mikrob lain seperti Salmonella dan Campylobacter di saluran pencernaan, sehingga kehadiran $B$. cereus dapat menekan jumlah mikrob tersebut. Dalam industri makanan ternak seperti ayam (Vila et al., 2009), kelinci (Bories et al., 2008), dan babi (Bories et al., 2007), beberapa strain $B$. cereus dimanfaatkan sebagai probiotik untuk menekan Salmonella di usus dan kaeka sehingga bermanfaat meningkatkan pertumbuhan. 
Bacillus cereus bersifat fakultatif aerobik, karena dapat memanfaatkan oksigen sebagai penerima elektron, dan sekaligus memiliki cara respirasi anaerobik sebagai mekanisme pelepasan energi (Duport et al., 2006). Dengan respirasi aerobik, produk glikolisis, dan siklus Krebs dioksidasi ulang melalui rantai transpor elektron menghasilkan ATP (Duport et al., 2006). Dengan respirasi anaerobik, B. cereus melakukan fermentasi untuk menghasilkan energi. Fermentasi mendaur ulang NAD+ dengan mereduksi pyruvate dan menghasilkan lactat dan ethanol (Duport et al., 2006). ATP dihasilkan dengan fosforilasi substrat.

Bacillus cereus dapat memetabolisme berbagai senyawa organik seperti protein, peptida, dan asam amino untuk pertumbuhan dan sumber energinya. Beberapa produk utama yang dimetabolisme dari sumber karbon sukrosa dan glukosa melalui respirasi anaerobik adalah L-lactat, acetat, format, succinat, ethanol, dan carbon dioxida (Mols et al., 2007). Pada respirasi nitrat, nitrate reductase merubah nitrat menjadi nitrit, lalu menjadi ammonium oleh enzim nitrite reductase (Mols et al., 2007).

Sebagai probiotik, Bacillus spp. sudah banyak diteliti karena memiliki kemampuan melekat dan menghasilkan bacteriosin (peptida antimikroba) dan imunostimulan (CladeraOlivera et al., 2004; Duc et al., 2004; Barbosa et al., 2005). Strain ini terbukti efektif sebagai produk probiotik komersial yang mampu meningkatkan produksi udang yang sama besarnya dengan apabila menggunakan antimikroba (Decamp \& Mortiarty, 2006). Bacillus spp. juga memiliki nilai tambah sebagai probiotik karena dapat disimpan dalam bentuk spora (Hong et al., 2005).

Staphylococcus epidermidis adalah bakteri gram positif yang berbentuk anggur jika dilihat di bawah mikroskop, bersifat fakultatif anaerob karena tumbuh baik dengan respirasi aerob ataupun fermentasi. S. epidermidis tidak dapat membentuk spora (Parisi, 1985). Meskipun sebagian besar S. epidermidis merupakan bakteri patogen oportunistik, tetapi hasil penelitian uji patogenisitas untuk strain ini tidak membuktikan bahwa ia patogen, sehingga strain S. epidermidis yang didapat ini memiliki potensi sebagai probiotik. Sebagaimana diketahui hal yang sama juga terjadi pada spesies Vibrio alginolyticus, bahwa sebagian strainnya merupakan patogen berbahaya bagi udang, namun sebagian lain justru merupakan probiotik yang sangat bermanfaat bagi ketahanan tubuh udang (Gomez-Gil et al., 2000).

\section{KESIMPULAN DAN SARAN}

Tahap isolasi mendapatkan sepuluh isolat, tahap uji zona hidrolisis protein mendapatkan empat isolat dengan zona hidrolisis tertinggi, sedangkan uji patogenisitas hanya meloloskan dua isolat, yaitu A1 dan L1. Hasil uji identifikasi biokimiawi dan molekuler menunjukkan bahwa isolat A1 adalah Staphylococcus epidermidis dan L1 adalah Bacillus cereus. B. cereus merupakan spesies yang sebagian besar anggotanya merupakan probiotik bagi hewan darat dan ikan. Dengan demikian dari penelitian ini didapatkan bahwa B. cereus merupakan kandidat bakteri yang berpeluang untuk dijadikan probiotik. Penelitian lanjutan yang sangat diharapkan adalah aplikasi bakteri probiotik ini dalam pakan ikan .

\section{UCAPAN TERIMA KASIH}

Ucapan terima kasih yang sebesar-besarnya terhadap DIPA Balai Riset Perikanan Budidaya Air Tawar Tahun Anggaran 2010 dan 2011 yang telah membiayai kegiatan penelitian ini.

\section{DAFTAR ACUAN}

Aslamyah, S. 2006. Penggunaan mikroflora saluran pencernaan sebagai probiotik untuk meningkatkan pertumbuhan dan kelangsungan hidup ikan bandeng (Chanos-chanos Forsskal). (Disertasi). Program Pasca Sarjana, Institut Pertanian Bogor. Bogor, $255 \mathrm{hlm}$.

Barbosa, T.M., Serra, C.R., La Ragione, R.M., Woodward, M.J., \& Henriques, A.O. 2005. Screening for Bacillus isolatres in the broiler gastrointestinal tract. Applied and Environmental Microbiology, 71(2):968978.

Bories, G., Brantom, P., Barberà, J.B., Chesson, A., Cocconcelli, P.S., Debski, B., Dierick, N., Gropp, J., Halle, I., Hogstrand, C., Knecht, J., Leng, L., Lindgren, S., Haldorsen, L., Mantovani, A., Mezes, M., Nebbia, C., Rambeck, W., Rychen, G., Wright, A., \& Wester, P. 2007. Opinion of the Scientific Panel on Additives and Products or Substances used in Animal Feed on the safety and efficacy of the product Toyocerin ( $\mathrm{Ba}$ cillus cereus var. Toyoi) as a feed additive for sows from service to weaning, in accordance with Regulation (EC) No 1831/ 
2003. (Question No EFSA-Q-2006-037). European Food Safety Authority. The EFSA Journal, 458: 1-9.

Bories, G., Brantom, P., Barberà, J.B., Chesson, A., Cocconcelli, P.S., Debski, B., Dierick, N., Gropp, J., Halle, I., Hogstrand, C., Knecht, J., Leng, L., Lindgren, S., Haldorsen, L., Mantovani, A., Mezes, M., Nebbia, C., Rambeck, W., Rychen, G., Wright, A., \& Wester, P. 2008. Safety and eficacy of the product Toyocerin (Bacillus cereus var. Toyoi) as feed additive for rabbit breeding does. Scientific Opinion of the Panel on Additives and Products or Substances used in Animal Feed. (Question No EFSA-Q2008-287). European Food Safety Authority. The EFSA Journal, 913: 1-13.

Cai, Y., Benno, T., Naskase, Y., \& Tae-Kwang, O. 1998. Specific probiotic characterization of Weisella hellenica DS-12 isolated from flounder intestine. Genet. Microbiol., 44: 311-316.

Cladera-Olivera, F., Caron, G.R., \& Brandelli, A. 2004. Bacteriosin-like substance production by Bacillus licheniformis strain P40. Letters in Applied Microbiology, 38: 251-256.

Decamp, O. \& Moriarty, D.J.W. 2006. Probiotics as alternative to antimicrobials: limitation and potential. World Aquaculture, 37(4): 6062.

Duc, L.H., Hong, H.A., Barbosa, T.M., Henriques, A.O., \& Cutting, S.M. 2004. Characterization of Bacillus probiotics available for human use. Applied and Environmental Microbiology, 70(4): 2,161-2,171.

Duport, C., Zigha, A., Rosenfeld, E., \& Schmitt, P. 2006. Control of Enterotoxin Gene Expression in Bacillus cereus F4430/73 Involves the Redox-Sensitive ResDE Signal Transduction System. Journal of Bacteriology, 188(18): 6,640-6,651.

Fuller, R. 1987. A review, probiotics in man and animals. Journal of Applied Bacteriology, 66: 365-378.

Gomez-Gil, B., Roque, A., \& Turnbull, J.F. 2000. The use and selection of probiotic bacteria for use in the culture of larval aquatic organisms. Aquaculture, 191: 259-270.

Gupta, A. \& Khare, S.K. 2006. A protease stable in organic solvents from tolerant strain of Pseudomonas aeruginosa. Bioresource Technology, 97: 1,788-1,793.

Hong, H.A., Duc, L.H., \& Cutting, S.M. 2005. The use of bacterial spore formers as probiotics. FEMS Microbiology Reviews, 29: 813-835.
Hoshino, T., Ishizaki, K., \& Sakamoto, T. 1997. Isolation of a Pseudomonas species from fish intestine that produces an active protease at low temperature. Lett. Appl. Microbiol., 25(1): 70-72.

Hungate, R. 1966. The Rumen and its Microbes. London and New York, Academic Press., $533 \mathrm{pp}$.

Jankauskiene, R. 2000. The dependence of the species composition of lactoflora in the intestinal tract of carps upon their age. Acta Zoologica Lituanica, 10(3): 78-83.

Mols, M., de Been, M., Zwietering, M.H., Moezelaar, R., \& Abee, T. 2007. Metabolic capacity of Bacillus cereus strains ATCC 14579 and ATCC 10987 interlinked with comparative genomics. Environmental Microbiology, 9(12): 2,933-2,944.

Nakayama, A., Yano, Y., \& Yoshida, K. 1994. New method for isolating Barophiles from intestinal contents of deep sea fishes retrieved from the abyssal zone. Appl. and Environm. Microbiol., 60(1 1): 4,210-4,212.

Nopitawati, T. 2010 . Seleksi bakteri probiotik dari saluran pencernaan untuk meningkatkan kinerja pertumbuhan udang vaname Litopenaeus vannamei. Tesis. Sekolah Pascasarjana Institut Pertanian Bogor. Bogor, $63 \mathrm{hlm}$.

Parisi, J.T. 1985. Coagulase-Negative Staphylococci and the Epidemiological Typing of Staphylococcus epidermidis. Microbiological Reviews, 49(2): 126-139.

Putra, A.N. 2010. Kajian probiotik, prebiotik dan sinbiotik untuk meningkatkan kinerja pertumbuhan ikan nila. Tesis. Program Pascasarjana, Institut Pertanian Bogor. Bogor, $91 \mathrm{hlm}$.

Rasko, D.A., Ravel, J., Okstad, O.A., Helgason, E., Cer, R.Z., Jiang, L., Shores, K.A., Fouts, D.E., Tourasse, N.J., Angiuoli, S.V., Kolonay, J., Nelson, W.C., Kolsto, A.B., Fraser, C.M., \& Read, T.D. 2004. The genome sequence of Bacillus cereus ATCC 10987 reveals metabolic adaptations and a large plasmid related to Bacillus anthracis pXO1. Nucleic Acids Research, 32(3): 977-988.

Rasko, D.A., Altherr, M.R., Han, C.S., \& Ravel, J. 2005. Genomics of the Bacillus cereus group of organisms. FEMS Microbiology Reviews, 29: 303-329.

Ryan, K.J., Ray, C.G., \& Sherris, J.C. (Eds.). 2004. Sherris Medical Microbiology (4th ed.). McGraw Hill. 979 pp.

Sabariah. 2010 . Seleksi bakteri probiotik dari 
saluran pencernaan untuk meningkatkan kinerja pertumbuhan ikan jelawat (Leptobarbus hoeveni Blkr). Tesis. Program Pascasarjana, Institut Pertanian Bogor. Bogor, $44 \mathrm{hlm}$.

Sahu, M.K., Swarnakumar, N.S., Silvakumar, K., Thangaradjou, T., \& Kannan, L. 2008. Probiotics in aquaculture: importance and future prospectives. Indian J. Microbiol., 48: 299-308.

Senesi, S., Celandroni, F., Salvetti, S., Beecher, D.C., Wong, A.C.L., \& Ghelardi, A. 2002. Swarming motility in Bacillus cereus and characterization of a fliY mutant impaired in swarm cell differentiation. Microbiology, 148: 1,785-1,794.

Suhartono, M.T. 1989. Enzim dan Bioteknologi. Departemen Pendidikan dan Kebudayaan. Direktorat Jenderal Pendidikan Tinggi. Antar Universitas Bioteknologi. Institut Pertanian Bogor. Bogor, $322 \mathrm{hlm}$.

Tang, X.Y, Pan, Y., Li, S., \& He, B.F. 2008. Screening and isolation of an organic solvent-tolerant bacterium for high-yield production of organic solvent-sable protease. Bioresource Technology, 99: 7,388-7,392.

Verschuere, L., Rombaut, G., Huys, G., Dhont, J., Sorgeloos, P., \& Verstracte, W. 2000. Probiotic bacteria as biological control agents in aquaculture, review. Microbiology and Molecular Biology Review, 64: 665671.

Vilà, B., Fontgibell, A., Badiola, I., Esteve-Garcia, E., Jiménez, G., Castillo, M., \& Brufau, J. 2009. Reduction of Salmonella enterica var. Enteritidis colonization and invasion by $\mathrm{Ba}$ cillus cereus var. toyoi inclusion in poultry feeds. Poultry Science, 88(55): 975-979.

Villain, S., Luo, Y., Hildreth, M., \& Brozel, V. 2006. Analysis of the Life Cycle of the Soil Saprophyte Bacillus cereus in Liquid Soil Extract and in Soil. Applied Environmental Microbiology, 72(7): 4970-4977.

Wang, B.Y., Li, R., \& Junda, L. 2008. Probiotics in aquaculture: challenges and outlook. Aquaculture, 281: 1-4.

Watson, A.K., Kaspar, H., Lategan, M.J., \& Gibson, L. 2008. Probiotics in aquaculture: the need, principles and mechanisms of action and screening processes. Aquaculture, 274: 1-14.

Wijnands, L, Dufrenne, J., Zwietering, M.H., \& Leusden, F. 2006. Spores from mesophilic Bacillus cereus strains germinate better and grow faster in simulated gastro-intestinal conditions than spores from psychrotrophic strains. International Journal of Food Microbiology, $112(2)$ : 120-128. 